\title{
Edirne İli Uzunköprü İlçesi Bağcılık Yapısının İncelenmesi
}

\author{
İlknur Korkutal $^{1 *} \quad$ Elman Bahar $^{1} \quad$ Damla Güvemli Dündar $^{2}$
}

\author{
${ }^{1}$ Namık Kemal Üniversitesi, Ziraat Fakültesi, Bahçe Bitkileri Bölümü, 59030, Tekirdağ. \\ ${ }^{2}$ Uzunköprü İlçe Tarım ve Orman Müdürlüğü, 22200, Edirne. \\ *Sorumlu yazar: ikorkutal@nku.edu.tr
}

Geliş Tarihi: 05.09.2018

Kabul Tarihi: 04.02.2019

$\ddot{O} z$

Araştırma populasyonunu Edirne ili Uzunköprü ilçesi Yeniköy Mahallesi, Kırcasalih Beldesi ve Aslıhan Köyü’ndeki üreticiler oluşturmaktadır. Araştırma sonlu populasyonda oranlar yardımıyla örnek hacmi belirleme yöntemine göre yapılmıştır. Çalışmada materyal olarak yöre bağları ve üreticileri seçilmiş ve örnekleme ile seçilen 115 üretici ile yüz yüze bir anket programı yürütülmüştür. Anket sonucunda; yöre bağlarının 10da'dan küçük olduğu ve Yeniköy mahallesinde Hamburg Misketi ve Alphonse Lavalleé, Kırcasalih beldesinde Papazkarası ve Merlot, Aslıhan köyünde ise Papazkarası ve Hamburg Misketi çeşitlerinin yoğun olarak yetiştirildiği belirlenmiştir. Yeniköy'de ankete katılan bağcıların \%30,56's1 1000kg/da; Kırcasalih'te \%44'ü $1000 \mathrm{~kg} / \mathrm{da}$ ve Aslıhan'da \%35,29'unun $500 \mathrm{~kg} / \mathrm{da}$ sofralık üzüm verimi almaktadır, ancak bu verim oldukça düşüktür. Ankete katılan bağcıların; Yeniköy \%27,91'i, Kırcasalih \%31,58'i ve Aslıhan \%5,88'i bağlarında sulama yapmaktadırlar. Bağcıların verim ve kaliteyi artırmak için sulama, gübreleme gibi kültürel işlemleri düzenli yapmaları gerekmektedir. Yeniköy bağlarının \%72,09'u, Kırcasalih bağlarının \%71,05'i ve Aslıhan bağlarının \%61,76'sı kimyasal gübre kullanmaktadır. Görüldüğü üzere üreticilerin çoğunluğu bağlarını kimyasal gübreler kullanarak gübrelemektedirler. Yeniköy bağlarının \%81,40'1, Kırcasalih bağlarının \%71,05'i ve Aslıhan bağlarının \%47,06'sı Kordon Royat şeklinde terbiye edilmiştir. Bu oran sadece Aslıhan köyünde \%50'nin altında kalmıştır. Tüm veriler incelendiğinde Yeniköy mahallesinin bağcılık konusunda daha bilinçli ve modern çalışmalarla üretimi sürdürdüğü, bunu Kırcasalih beldesinin izlediği ortaya konmuştur. Aslıhan köyü bağları 2015 yılında yaşanılan sel felaketinden sonra eski haline dönememiştir. Ayrıca yöreye özgü Papazkarası çeşidinin yetiştiriciliğinin devam etmesi ve geliştirilmesi için gereken düzenlemelerin en kısa sürede yapılması da yerinde olacaktır.

Anahtar Kelimeler: Bağcılık, Aslıhan, Kırcasalih, Yeniköy, Edirne, Türkiye

\section{Examination of the Vineyard Structure of Edirne Province Uzunköprü Country}

\section{Abstract}

The population of this study is the producers in the Yeniköy district of Uzunköprü county of Edirne, Kircasalih town and Aslihan village. The study was carried out according to sample volume determination method with the help of proportions in the end population. In the study, vineyards and the grape producers were selected as the material and a face to face survey program was conducted with 115 producers who were selected by sampling method. It was determined that in the Yeniköy, Muscat of Hamburg and Alphonse Lavalleé cv's; in Kircasalih Papazkarasi and Merlot cv's; also in Aslihan Papazkarasi and Muscat of Hamburg cv's were widely grown in the region. In Yeniköy, $30.56 \%$ of the surveyors were $1000 \mathrm{~kg} / \mathrm{da}$; In Kırcasalih, $44 \%$ of it is $1000 \mathrm{~kg} / \mathrm{da}$ and in Aslihan 35,29\% of 500kg/da table grape yield was taken, but this yield is low. Yeniköy $27,91 \%$ of the vineyards, Kircasalih $31,58 \%$ and Aslihan 5,88\% of the vineyards were irrigated their vineyards. In order to increase the yield and quality, vigneron's should carry out cultural activities such as irrigation and fertilization regularly. It was stated that the $72,09 \%$ of Yeniköy vineyards, $71,05 \%$ of Kircasalih vineyards and $61,76 \%$ of Aslihan vineyards use chemical fertilizers. As it seen, most of the producers fertilize their vineyards by using chemical fertilizers. When examining the training systems; it was determined that the $81,40 \%$ of Yeniköy vineyards, $71,05 \%$ of Kircasalih vineyards and 47,06\% of Aslihan vineyards were trained as Kordon Royat. This rate was only below $50 \%$ in the village of Aslihan. When all the data were analyzed, it was revealed that Yeniköy district has more conscious and modern techniques on viticulture and this was followed by Kircasalih town. It was specified that the Aslihan village vineyards could not be restored after the flood in 2015. In addition, it will be appropriate to make an arrangements for the protect an autochthonous cv. Papazkarasi as soon as possible.

Keywords: Viticulture, Aslıhan, Kırcasalih, Yeniköy, Edirne, Turkey 


\section{Giriş}

Türkiye'nin bitkisel üretiminde bağcılık sektörü önemli bir yer almaktadır. Uygun ve elverişli yetiştirme olanaklarına sahip olan Türkiye'de bağcılık eski ve köklü bir kültüre dayanmaktadır (Baykul ve ark., 2018). Üzüm, iklim ve toprak yönünden fazla seçici olmaması ve alternatif değerlendirme olanaklarına sahip olması nedeniyle dünyada ve Türkiye'de yaygın kültür bitkilerinden biridir. 2017 yılı TÜİK verilerine göre Türkiye'de yaklaşık 417.000 ha alanda 4.2 Milyon Ton civarında üzüm üretimi gerçekleştirilmiştir (Anonim, 2018a).

Marmara Bölgesi toplam bağ alanı 18.735 ha olup üzüm üretim miktarı 197.923 ton'dur. Bölgenin Trakya kesiminde şaraplık, Anadolu tarafında ise orta mevsim ve geç mevsimde olgunlaşan sofralık üzüm çeşitleri yetiştirilmektedir. Edirne ve Tekirdağ'da şaraplık üzüm üretimi çok yaygındır ve ürünler genellikle özel sektöre ait şarap fabrikalarında değerlendirilmektir.

Edirne ili Marmara Bölgesi'nin Trakya kısmında yer almakta ve $6.279 \mathrm{~km}^{2}$ ’lik yüz ölçüme sahip bulunmaktadır. İl, 8 ilçe ve kendisine bağlı 248 köyden oluşmakta ve topraklarının \%80'i tarıma elverişli olup, toplam 370.948 ha tarımsal araziye sahiptir. Tarım arazisinin \%1,09'u meyve-bağ arazisinden oluşmaktadır.

Edirne ili ve ilçeleri toplam bağ alanı 18.985 da olup, bunun 10.705 dekarı sofralık ve 8.280 dekarı şaraplık üzüm çeşitlerinden oluşmaktadır. İle bağlı Uzunköprü ilçesi toplam bağ alanı 12.301 da olup, bunun 5.781 dekarı sofralık ve 6.520 dekarı şaraplık olarak değerlendirilmektedir (Anonim, 2018b). Günümüz verilerini 2009 verileriyle kıyasladığımızda Edirne ili toplam bağ alanlarının \%16,7 oranında azalmış olduğu görülüp Uzunköprü ilçesi için verilerde herhangi bir değişikliğe rastlanmamıştır (Korkutal ve ark., 2009).

Yeniköy, Uzunköprü'nün bağ varlığı bakımından önde gelen mahallelerinden biri olup, Kırcasalih ve Aslıhan'a göre üzüm yetiştiriciliği daha fazla yapılmaktadır. Kırcasalih beldesinde 1973 yılında Tekel tarafindan bir şarap fabrikası kurulmuştu (Utku, 2015). Ancak günümüzde Yeniköy’de sadece özel bir firmaya ait şarap fabrikası bulunmaktadır (Anonim, 2018c).

Tarihsel olarak da bir bağcılık geçmişine sahip olan Yeniköy, Kırcasalih ve Aslıhan bağcılığının konu olarak incelenmesindeki amaç; bağcılık açısından uygun özelliklere sahip olan Edirne ili Uzunköprü ilçesi Yeniköy mahallesi, Kırcasalih beldesi ve Aslıhan köyündeki 2018 yılı bağcılık profilini tanımlamaktadır.

\section{Materyal ve Yöntem \\ Materyal}

Araştırma materyali; Edirne ili Uzunköprü ilçesi Yeniköy mahallesi, Kırcasalih beldesi ve Aslıhan köyünde bağcılık yapan üreticilerdir (Şekil 1, 2, 3). Coğrafi konum olarak Yeniköy mahallesi $41^{\circ} 20^{\prime} 40.05^{\prime}$ ' kuzey enlemi ile $26^{\circ} 46^{\prime} 11.76^{\prime}$ ' doğu boylamı arasında, Kurcasalih beldesi $41^{\circ} 22^{\prime}$ 44. $04^{\prime}$ ' kuzey enlemi ile $26^{\circ} 48^{\prime} 25$. $01^{\prime \prime}$ ' doğu boylamı arasında ve Aslihan köyü $41^{\circ} 24^{\prime} 43.05^{\prime}$, kuzey enlemi ile $26^{\circ} 47^{\prime} 41.07^{\prime}$ ' doğu boylamı arasında yer almaktadır.

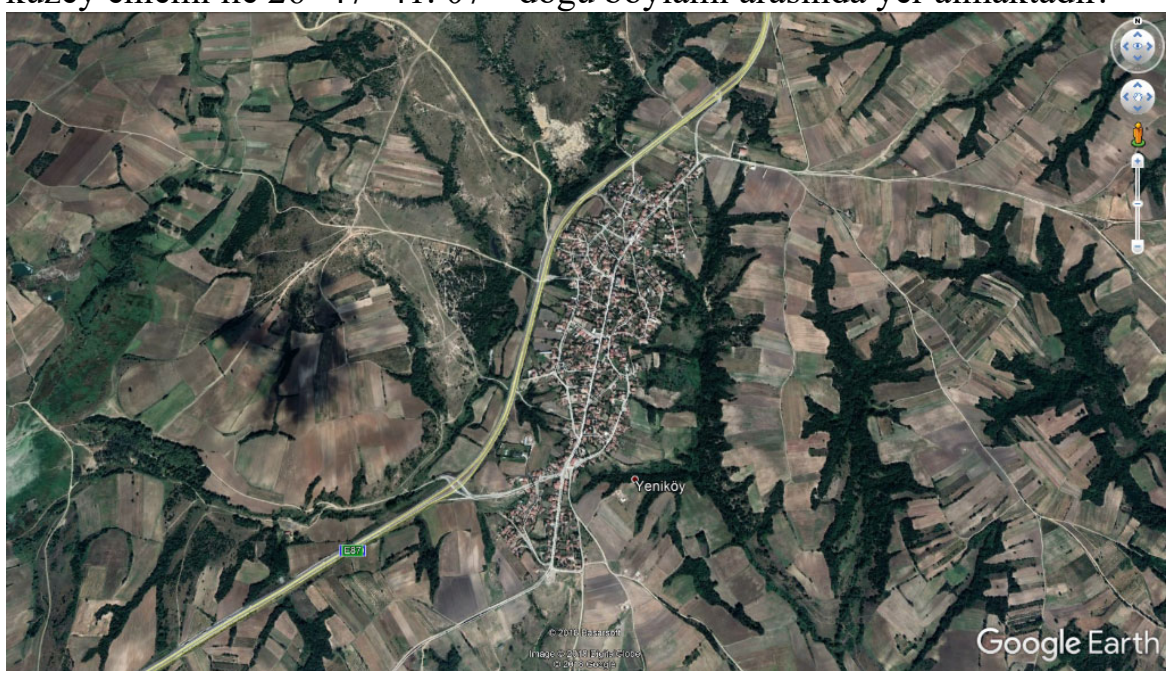

Şekil 1. Yeniköy mahallesinin uydu görüntüsü (Google Earth, 2019). 


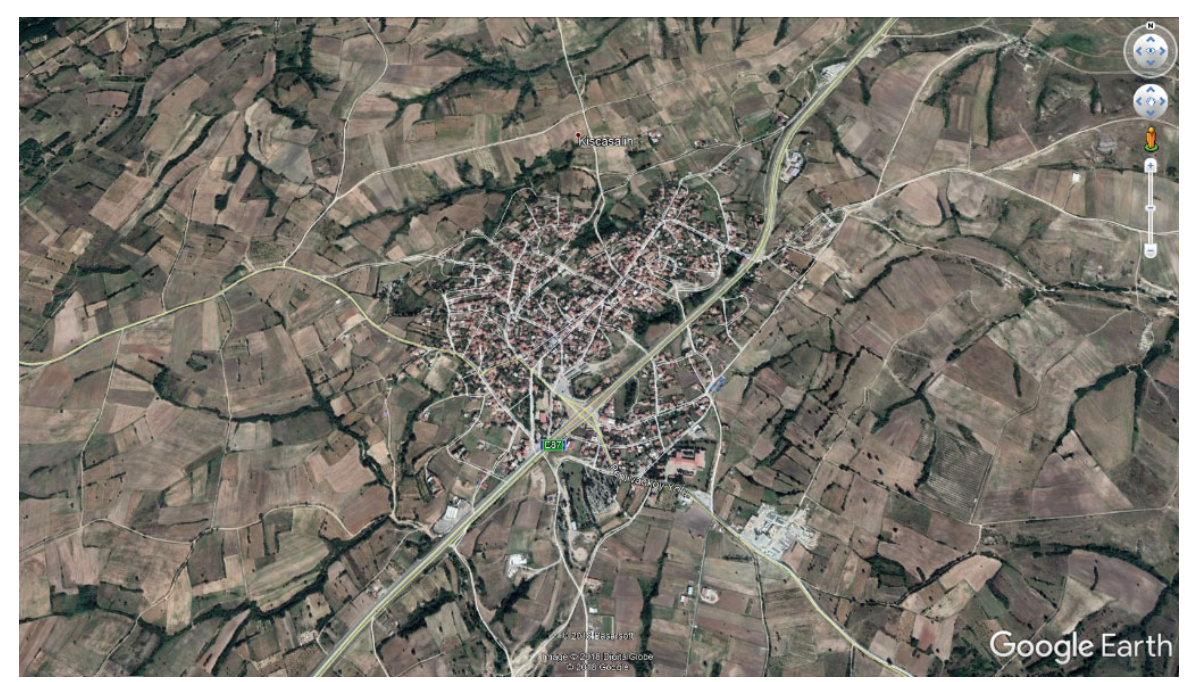

Şekil 2. Kırcasalih beldesinin uydu görüntüsü (Google Earth, 2019).

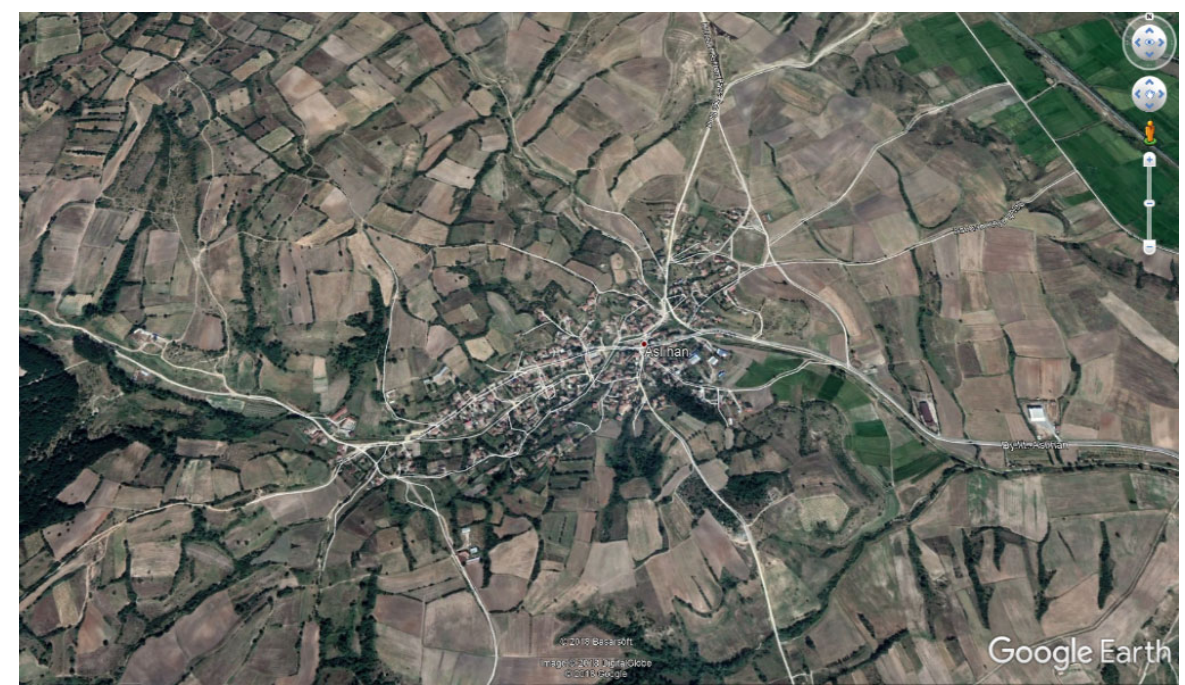

Şekil 3. Aslıhan köyünün uydu görüntüsü (Google Earth, 2019).

\section{Yöntem}

$\mathrm{Bu}$ çalışma üreticilerle anket yolu ile elde edilen birincil verilere dayanmaktadır. Araştırmaya konu olan Yeniköy mahallesinde yaşayan ve bağcılıkla uğraşan 115, Kırcasalih beldesinde 85 ve Aslıhan köyünde 67 bağcı saptanmıştır. Bu bağcılardan Yeniköy Mahallesi için 43 üretici, Kırcasalih beldesi için 38 üretici ve Aslıhan köyü için 34 üretici ile anket yapılmıştır. Anket kapsamında yörenin bağcılık yapısını belirlemek amacıyla 42 anket sorusu hazırlanmıştır. Bu sorular 115 üreticiye tek tek sorulmuş ve verilen yanıtlar aynı anda soru-yanıt şeklinde kaydedilmiştir. Ankete katılan bağcılar rastlantısal olarak seçilmiştir.

Sonlu popülasyonda oranlar yardımıyla örnek hacmi belirleme yöntemine göre yapılmıştır. $\mathrm{Bu}$ yöntemle $\% 90$ güven katsayısı ve \%10 hata payı ile örnek hacmi belirlenmiştir (Miran, 2002; Güler, 2014).

$\mathrm{n}=\mathrm{N} \cdot \mathrm{p} . \mathrm{q} /(\mathrm{N}-1)\left(\mathrm{Z}_{\alpha / 2} / \mathrm{d}\right)^{2}+\mathrm{p} . \mathrm{Q}$

Formüldeki; $\mathrm{n}=$ Denek sayısı, $\mathrm{N}=$ Bağc1lık işletme sayısı, $\mathrm{p}=$ Populasyon oranı, $\mathrm{q}=$ Anakitle varyansı, $Z=$ Seçilen olasılık düzeyi için normal dağılış tablo değeri ve $d=$ Hata değerini göstermektedir.

Ayrıca konu ile ilgili yapılmış olan diğer çalışmalardan ve diğer kurumlardan derlenen ikincil istatiksel verilerden de yararlanılmıştır. Anket sonuçları \% metodu kullanılarak değerlendirilmiştir (Polat ve ark., 2018). 


\section{Bulgular ve Tartışma}

Araştırma bulguları içerisinde ankette sorulan 42 sorunun da cevapları ayrı ayrı sunulmamış, yöre bağcıllğını tanımlamak amacıyla önemli bulunan konular üzerinde durulmuştur. Ankete katılan Yeniköy, Kırcasalih ve Aslıhan bağcılarının bağ parsel büyüklüklerinin genellikle 10 dekardan küçük olduğu saptanmış olup ülkemizin bağ alanlarının entansif bağcılık yapmak için yeterince büyük (Bahar ve ark., 2006; Karataş ve ark., 2018) ve öte yandan Çelik ve ark. (2005)'nın belirttikleri ekonomik düzeyde ürün ve gelir elde edilen bağlar olmadığı bulgusuyla paralel olduğu görülmüştür (Çizelge 1).

Çizelge 1. Bağ parsel büyüklükleri

\begin{tabular}{llllllr}
\hline Bağ & Yeniköy & \multicolumn{3}{c}{ Kslicasalih } \\
büyüklüğü & İşletme sayısı & Oranı (\%) & İşletme sayısı & Oranı (\%) & İşletme sayısı & Oranı (\%) \\
\hline $1-4 \mathrm{da}$ & 24 & 55,81 & 17 & 44,74 & 8 & 23,53 \\
$5-9 \mathrm{da}$ & 13 & 30,23 & 17 & 44,74 & 18 & 52,94 \\
$10-14 \mathrm{da}$ & 1 & 2,33 & 4 & 10,53 & 8 & 23,53 \\
$15-19 \mathrm{da}$ & 2 & 4,65 & 0 & 0,00 & 0 & 0,00 \\
$>20 \mathrm{da}$ & 3 & 6,98 & 0 & 0,00 & 0 & 0,00 \\
\hline Toplam & 43 & 100,00 & 38 & 100,00 & 34 & 100,00 \\
\hline
\end{tabular}

Anket sonucunda, Yeniköy bağlarının $(\% 32,56)$ 11-15 yaş aralığında; Kırcasalih bağlarının $(\% 39,47)$ 6-10 yaş aralığında; her iki köy için ortalama yaşın 6-15 arasında değiştiği; Aslıhan köyü bağlarının $(\% 41,18)$ ise genellikle 16-20 yaş aralığında olduğu belirlenmiştir. Aslıhan üreticilerinin vermiş olduğu yanıtlara baktığımızda aileden kalan bağlarda üretimin sürdürüldüğüu, çok fazla yeni bağ tesisi kurulmadığı görülmüştür (Çizelge 2).

Çizelge 2. Bağ yaşları

\begin{tabular}{lllllll}
\hline Bağ yaşları & Yeniköy & \multicolumn{3}{c}{ Kurcasalih } & \multicolumn{3}{c}{ Aslihan } \\
\cline { 2 - 7 } & Üretici sayıs1 & Oranı (\%) & Üretici sayıs1 & Oranı (\%) & Üretici sayıs1 & Oran1 (\%) \\
\hline $0-5$ & 11 & 25,58 & 5 & 13,16 & 1 & 2,94 \\
$6-10$ & 6 & 13,95 & 15 & 39,47 & 3 & 8,82 \\
$11-15$ & 14 & 32,56 & 11 & 28,95 & 9 & 26,47 \\
$16-20$ & 1 & 2,33 & 4 & 10,53 & 14 & 41,18 \\
$>21$ & 11 & 25,58 & 3 & 7,89 & 7 & 20,59 \\
\hline Toplam & 43 & 100,00 & 38 & 100,00 & 34 & 100,00 \\
\hline
\end{tabular}

Yeniköy mahallesinde bağcılar, Hamburg Misketi ve Alphonse Lavalleé; Kırcasalih beldesinde Papazkarası ve Merlot; Aslıhan köyünde ise Papazkarası ve Hamburg Misketi çeşitlerini yetiştirdiklerini belirtmişlerdir. Yörede çok eski bir geçmişe sahip otokton çeşit olan Papazkarası üzüm çeşidinin yetiştiriciliğinin devam etmesi olumlu bir bilgidir. Bu çeşidin Kırcasalih ve Aslıhan'da yoğun olarak yetiştirildiği 1968 yılı TBMM Tutanakları'nda yer almıştır (Anonim, 2019). Yeniköy'de 2009 y1lında yapılan bir çalışmada (Korkutal ve ark., 2009) şaraplık bir çeşit olan Merlot ilk sıradayken, günümüzde yerini Hamburg Misketi çeşidinin aldığı saptanmıştır (Şekil 4). Son yıllarda fenolik madde içerikleri nedeniyle renkli çeşitler sofralık ve şaraplık olarak tercih edilmektedir (Çelik, 2019). Bu eğilim dikkate alındığında sofralık ve şaraplık olarak yörede yetiştirilen çeşitler renkleri nedeniyle bu trendi yakalamıştır. 


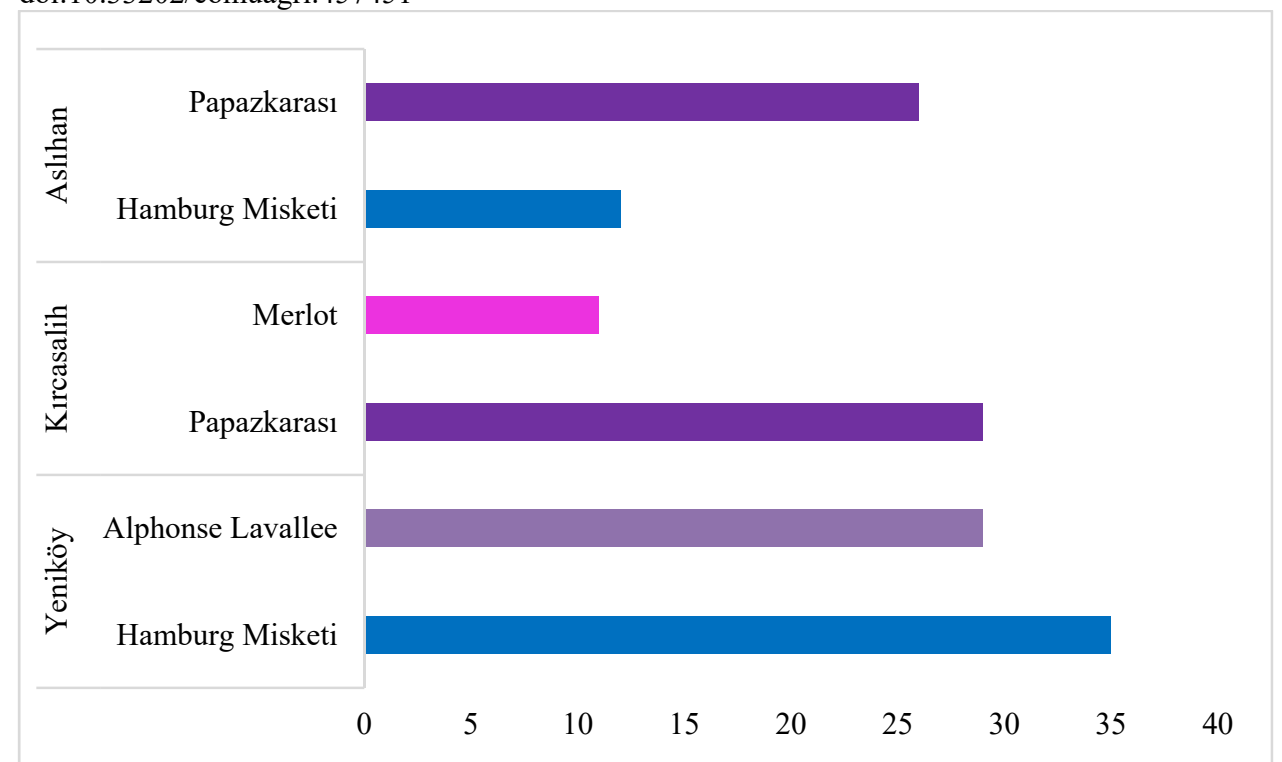

Şekil 4. Yeniköy, Kırcasalih ve Aslıhan'da en çok yetiştirilen iki üzüm çeşidi.

Bağ kurmada, Yeniköy mahallesi ve Kırcasalih beldesinde aşı11-köklü asma fidanı kullanımı yoğun iken Aslıhan köyünde yerli çelik (kültür çeşidi) ile üretim tercih edilmiştir. Kıbrıs'ta ve Şanlıurfa'da yapılan çalışmalarda bağcıların çoğunun anaç kullanmaksızın yetiştirilen fidanlarla Aslıhan Köyündeki gibi bağ kurduğu görülmüştür (Göksu ve ark., 2015; Polat ve ark., 2018; Çetin ve Daler, 2018; Karataș ve ark., 2018; Kiraz ve ark., 2016). Bilindiği gibi ülkemizin bağcılık yapılan tüm bölgeleri, filoksera ve nematodlarla bulaşık olduğundan, bağ tesisinde ya doğrudan aşılı fidan kullanılması ya da dikilen aşısız (Amerikan asma anacı) fidanların bağda aşılanması gerekmektedir (Dardeniz, 2013; Çelik, 2019). Bu nedenle yeni kurulacak olan bağlarda aşıl1-köklü fidan ile yetiştiricilik yapılması üreticilere özendirilmelidir ve gerekirse de ücretsiz aşılı-köklü fidan dağıtımı şeklinde kuruluşlarca desteklenmelidir (Şekil 5, 6, 7).
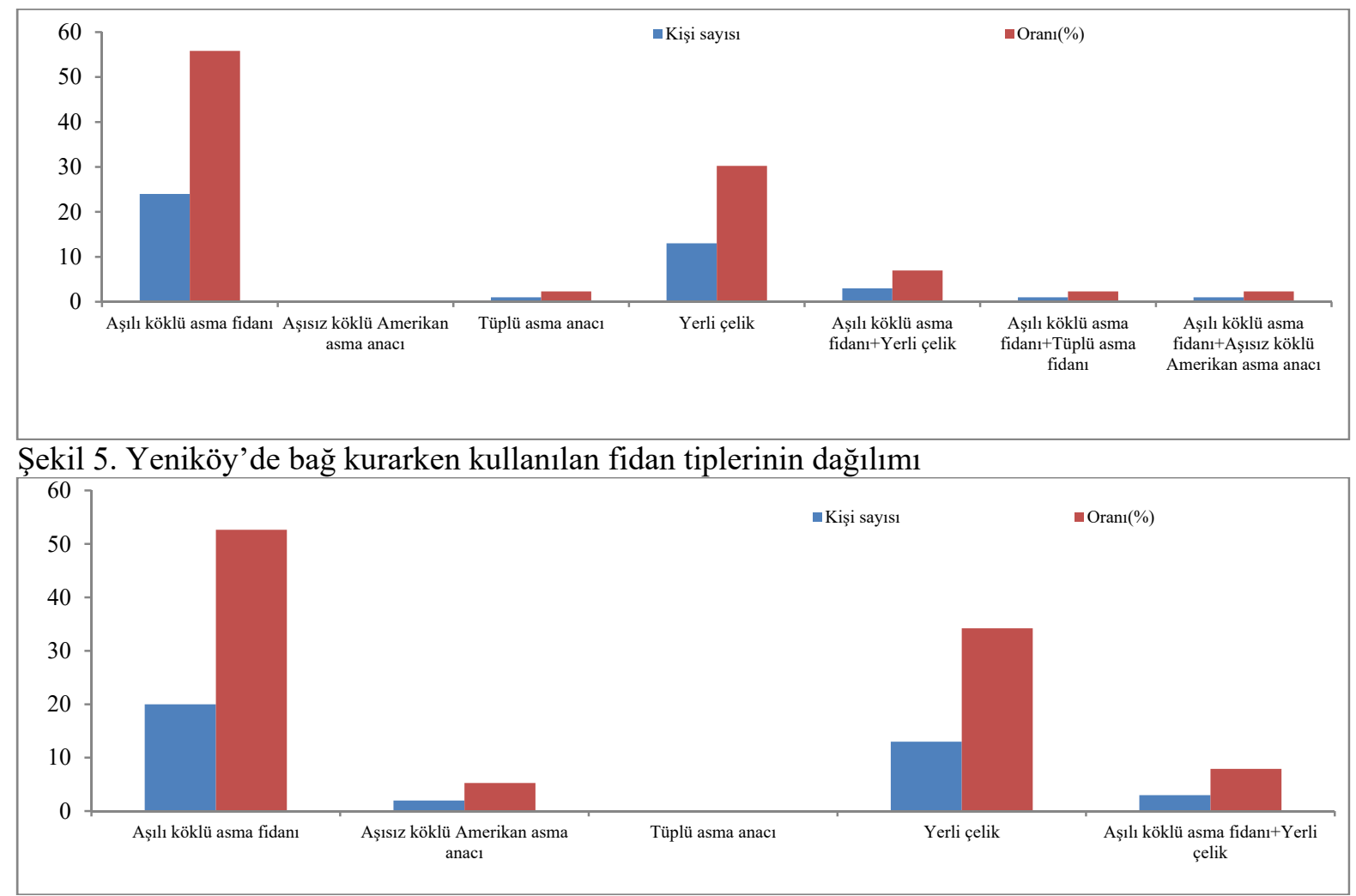

Şekil 6. Kırcasalih’te bağ kurarken kullanılan fidan tiplerinin dağılımı 


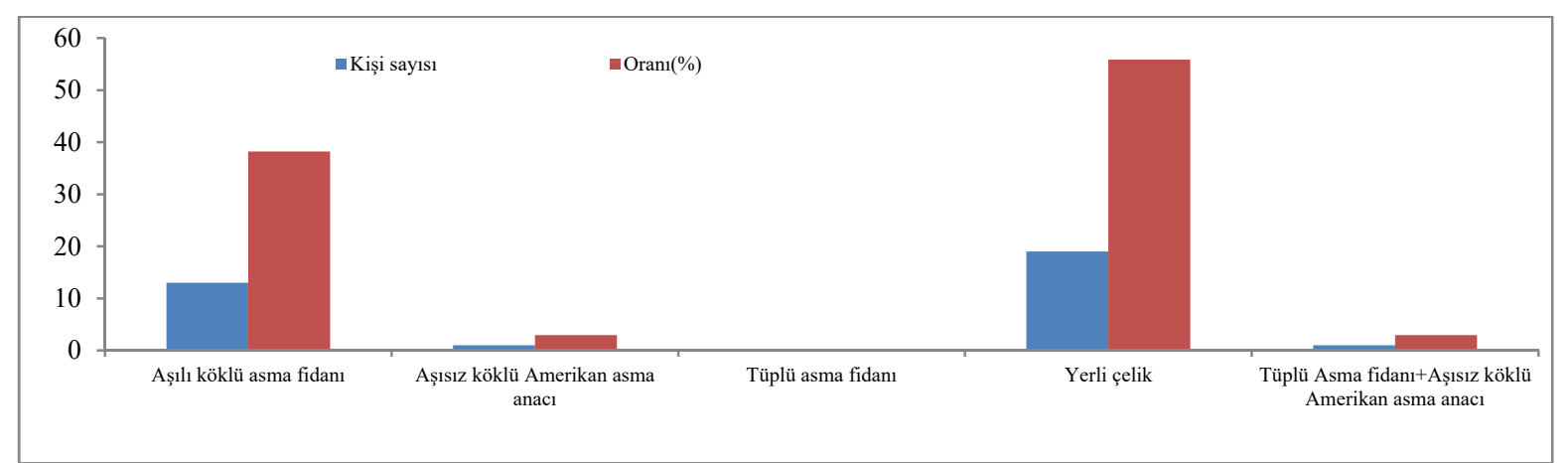

Şekil 7. Aslıhan'da bağ kurarken kullanılan fidan tiplerinin dağılımı

Ankete katılan bağcıların büyük çoğunluğu aşıl1-köklü asma fidanı fiyatlarının pahalı olduğunu belirtmiş; Bahar ve ark. (2006)'nın belirttiği gibi fidan fiyatlarının talep artışıyla birlikte arttığını göstermesi bakımından dikkate değer bulunmuştur. Çelik (2019) ve Savaş ve ark. (2015), ülkemiz aşılı-köklü fidan randımanının düşük kaldığını vurgulamışlardır.

Yörede bağlarda dikim aralık ve mesafesinin $3 \mathrm{~m}$ x 1-1,5m olduğu belirlenmiş, oldukça geniş verilen sıra arası mesafesinin $(3 \mathrm{~m})$ bağcıların bahçe traktörüne sahip olmamalarından kaynaklandığı sonucuna varılmıştır. Öte yandan bağda toprak işleme, yabancı ot mücadelesi, ilaçlamada tamamen mekanizasyondan yararlanıldığı bulgusu da göz ardı edilmemelidir (Çizelge 3). Ancak sulama oranının da düşük olduğu (yaklaşık \%20) görülmektedir. Sulanan bağ alanlarının artırılması gerekmektedir (Kiracı ve ark., 2015). Bağ içerisine kurulan damla sulama ve modern destekleme sistemleri Avrupa ülkelerinde devlet tarafindan finanse edilmektedir, hatta Kuzey Amerika'da sofralık üzüm yetiştirilen bağlarda sulama zorunluluğu vardır (Sivritepe ve Parlak, 2015). Ülkemizde de desteklenirse üreticilerin geliri artacaktır.

Çizelge 3. Mekanizasyondan yararlanılarak yapılan işler

\begin{tabular}{|c|c|c|c|c|c|c|}
\hline \multirow{2}{*}{ Yapılan işler } & \multicolumn{2}{|c|}{ Yeniköy } & \multicolumn{2}{|c|}{ Kurcasalih } & \multicolumn{2}{|c|}{ Aslihan } \\
\hline & $\begin{array}{l}\text { Üretici } \\
\text { say1S1 }\end{array}$ & Oranı $(\%)$ & $\begin{array}{l}\text { Üretici } \\
\text { sayıs1 }\end{array}$ & Oranı (\%) & $\begin{array}{l}\text { Üretici } \\
\text { sayıs1 }\end{array}$ & Oranı $(\%)$ \\
\hline Toprak işleme & 43 & 100,00 & 38 & 100,00 & 34 & 100,00 \\
\hline Yabanc1 ot mücadelesi & 43 & 100,00 & 38 & 100,00 & 34 & 100,00 \\
\hline İlaçlama & 43 & 100,00 & 38 & 100,00 & 34 & 100,00 \\
\hline Gübreleme & 43 & 100,00 & 38 & 100,00 & 34 & 100,00 \\
\hline Sulama & 12 & 27,91 & 12 & 31,58 & 2 & 5,88 \\
\hline
\end{tabular}

Yeniköy Mahallesi ve Kırcasalih Beldesi'nde bağcıların çoğunluğu Kordon Royat terbiye şeklini kullanmakta olup, yöre bağcillğında yeniliklerin takip edildiği ve yeni bağların modern yöntemlerle tesis edildiği görülmektedir. Aslıhan Köyü'nde ise Kordon Royat ve Goble terbiye şeklinin kullanım oranlarının birbirine çok yakın olduğu belirlenmiş olup ekstantif tarıma dayalı üretimin olduğu saptanmıştır (Şekil 8). Maalesef destekleme sisteminde kullanılan materyallerin (direk ve tel) fiyatlarının yüksek olması; hala Goble Terbiye Şekli (telli destekleme sistemi olmadan) ile bağların kurulmasını gündemde tutmaktadır (Bahar ve ark., 2006; Semerci ve ark., 2015; Baykul ve Söylemzoğlu, 2018; Çetin ve Daler, 2018; Özatak ve ark., 2018).
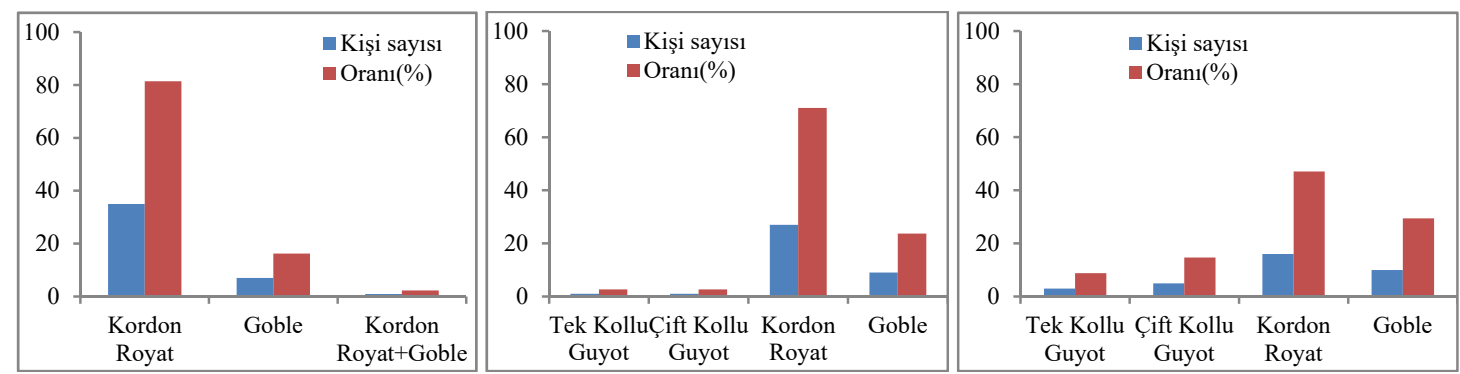

Şekil 8. Yeniköy, Kırcasalih ve Aslıhan bağlarında kullanılan terbiye sistemleri. 
Yeniköy, Kırcasalih ve Aslıhan'da bağ parselleri küçük ve üreticiler aile işletmesi şeklinde faaliyetlerini sürdürmektedirler. Bu nedenle de üreticilerin bağlarındaki kültürel işlemleri kendilerinin yaptıkları sonucu ortaya çıkmıştır. Asmanın verim ve kalitesini önemli derecede etkileyen gübreleme ve hangi tip gübrelerin kullanıldığ 1 sorulduğunda üreticilerin büyük çoğunluğunun kimyasal gübre kullandığ 1 ve dekara ortalama 30-50kg gübre verdiği belirlenmiştir (Çizelge 4). Bu gübreleri yıllardır sürdükleri bağcılık tecrübelerine dayanarak uyguladıkları da kaydedilmiştir.

Çizelge 4. Kullanılan gübreler

\begin{tabular}{|c|c|c|c|c|c|c|}
\hline \multirow[t]{2}{*}{ Gübre tipi } & \multicolumn{2}{|c|}{ Yeniköy } & \multicolumn{2}{|c|}{ Kircasalih } & \multicolumn{2}{|l|}{ Aslihan } \\
\hline & $\begin{array}{l}\text { Üretici } \\
\text { say1s1 }\end{array}$ & Oranı $(\%)$ & $\begin{array}{l}\text { Üretici } \\
\text { say1s1 }\end{array}$ & Oranı $(\%)$ & $\begin{array}{l}\text { Üretici } \\
\text { say1s1 }\end{array}$ & Oranı $(\%)$ \\
\hline Çiftlik gübresi & 1 & 2,33 & 1 & 2,63 & 2 & 5,88 \\
\hline Kimyasal gübre & 31 & 72,09 & 27 & 71,05 & 21 & 61,76 \\
\hline Organik gübre & 1 & 2,33 & 0 & 0 & 1 & 2,94 \\
\hline Çiftlik gübresi+Kimyasal gübre & 8 & 18,60 & 8 & 21,05 & 5 & 14,71 \\
\hline $\begin{array}{l}\text { Kimyasal gübre+Yaprak gübresi } \\
\text { Kimyasal gübre+Yaprak gübresi }\end{array}$ & 1 & 2,33 & 1 & 2,63 & 4 & 11,76 \\
\hline $\begin{array}{l}\text { + Organik gübre } \\
\text { Kimyasal gübre+Yaprak gübresi }\end{array}$ & 1 & 2,33 & 0 & 0 & 0 & 0 \\
\hline + Organik gübre+Çiftlik gübresi & 0 & 0 & 0 & 0 & 1 & 2,94 \\
\hline Kimyasal gübre+Organik gübre & 0 & 0 & 1 & 2,63 & 0 & 0 \\
\hline Toplam & 43 & 100,00 & 38 & 100,00 & 34 & 100,00 \\
\hline
\end{tabular}

Yeniköy Mahallesi, Kırcasalih Beldesi ve Aslıhan Köyü bağcılarına vejetasyon periyodu boyunca karşılaştıkları hastalık ve zararlılar sorulduğunda; bağlarında en çok Külleme (Uncinula necator) ve Mildiyö (Plasmopara viticola) hastalıklarını gördüklerini belirtmişlerdir. Aynı ifade Korkutal ve ark. (2009) tarafından Yeniköy mahallesinde yapılmış olan araştırma bulgularıyla paraleldir. Yeniköy ve Kırcasalih'te en çok görülen zararlılar da Bağ uyuzu (Eriophyes vitis) ve Dürmece (Sparganothis pilleriana) olup Korkutal ve ark. (2009)'nın verileri ile paralellik göstermektedir. Aslıhan'da ise daha çok Salkım güvesi (Lobesia botrana) zararlısının görüldüğü saptanmıştır. Ayrıca yöre bağcıları, bağlarında yabancı ot olarak; Yeniköy'de papatya (Asteraceae sp.) ve üçgülün (Trifolium sp.); Kırcasalih ve Aslıhan'da ise ayrık otunun (Elytrigia repens) görüldüğünü ifade etmişlerdir.

Şaraplık üzüm veriminin Yeniköy ve Kırcasalih’te $500 \mathrm{~kg} / \mathrm{da}$ iken, Aslıhan köyünde $600 \mathrm{~kg} / \mathrm{da}$ olduğu belirlenmiştir. Buradan hareketle şaraplık üzüm yetiştiren üreticilerin verimden çok kaliteye önem verdiği (Bahar ve ark., 2006) ve üreticilerde belirli bir bağc1lık bilincinin geliştiği görülmüştür (Çizelge 5).

Çizelge 5. Yöredeki şaraplık üzüm verimleri

\begin{tabular}{|c|c|c|c|c|c|c|}
\hline \multirow{2}{*}{$\begin{array}{l}\text { Şaraplık üzüm } \\
(\mathrm{kg} / \mathrm{da})\end{array}$} & \multicolumn{2}{|l|}{ Yeniköy } & \multicolumn{2}{|l|}{ Kircasalih } & \multicolumn{2}{|l|}{ Aslihan } \\
\hline & Üretici say1S1 & Oranı (\%) & Üretici say1s1 & Oranı (\%) & Üretici say1s1 & Oranı (\%) \\
\hline $1500 \mathrm{~kg}$ & 1 & 3,23 & 0 & 0,00 & 0 & 0,00 \\
\hline $1250 \mathrm{~kg}$ & 1 & 3,23 & 0 & 0,00 & 0 & 0,00 \\
\hline $1000 \mathrm{~kg}$ & 2 & 6,45 & 1 & 2,94 & 0 & 0,00 \\
\hline $800 \mathrm{~kg}$ & 2 & 6,45 & 2 & 5,88 & 0 & 0,00 \\
\hline $700 \mathrm{~kg}$ & 5 & 16,13 & 11 & 32,35 & 4 & 13,79 \\
\hline $650 \mathrm{~kg}$ & 3 & 9,68 & 2 & 5,88 & 8 & 27,59 \\
\hline $600 \mathrm{~kg}$ & 0 & 0,00 & 5 & 14,71 & 10 & 34,48 \\
\hline $550 \mathrm{~kg}$ & 5 & 16,13 & 2 & 5,88 & 3 & 10,34 \\
\hline $500 \mathrm{~kg}$ & 10 & 32,26 & 11 & 32,35 & 4 & 13,79 \\
\hline $450 \mathrm{~kg}$ & 1 & 3,23 & 0 & 0,00 & 0 & 0,00 \\
\hline $400 \mathrm{~kg}$ & 0 & 0,00 & 0 & 0,00 & 0 & 0,00 \\
\hline $300 \mathrm{~kg}$ & 1 & 3,23 & 0 & 0,00 & 0 & 0,00 \\
\hline Toplam & 31 & 100,00 & 34 & 100,00 & 29 & 100,00 \\
\hline
\end{tabular}

Sofralık üzüm verimi ise Yeniköy ve Kırcasalih'te ortalama $1000 \mathrm{~kg} / \mathrm{da}$ olarak saptanmış olup Korkutal ve ark. (2009) verilerine göre sofralık üzümlerden alınan verimin geçen dokuz yılda arttı̆̆ gözlenmiştir (Çizelge 6). Ancak Aslıhan köyünde sofralık üzümden elde edilen verim ortalama 500 
$\mathrm{kg} / \mathrm{da}$ 'dır. Buradaki bağcılarla yapılan anket esnasında; bağ masraflarının fazla olduğu ve yapmakta oldukları yetiştiricilik sonucunda bir gelir elde edemedikleri bilgileri alınmıştır. Bu bulgu Semerci ve ark. (2015)'nın ortaya koydukları birim alandan elde edilen verim düzeyinin istenilen seviyede olmadığı bulgusuyla uyum içindedir. Ayrıca sofralık üzüm çeşitlerinin daha düşük fiyata satılmasından dolayı; şaraplık üzüm verim ve kalitesine daha çok önem verdikleri belirlenmiştir (Anonim, 2018d).

Çizelge 6. Yöredeki sofralık üzüm verimleri

\begin{tabular}{llllllr}
\hline \multirow{2}{*}{$\begin{array}{l}\text { Sofralık üzüm } \\
\mathrm{kg} / \mathrm{da}\end{array}$} & Yeniköy & \multicolumn{3}{c}{ Kircasalih } \\
\cline { 2 - 7 } $1500 \mathrm{~kg}>$ & Üretici sayıs1 & Oranı (\%) & Üretici sayıs1 & Oranı (\%) & Üretici sayıs1 & Oranı (\%) \\
$1200 \mathrm{~kg}$ & 3 & 11,11 & 0 & 0,00 & 0 & 0,00 \\
$1000 \mathrm{~kg}$ & 11 & 8,33 & 3 & 12,00 & 0 & 0,00 \\
$900 \mathrm{~kg}$ & 2 & 30,56 & 11 & 44,00 & 2 & 11,76 \\
$800 \mathrm{~kg}$ & 5 & 5,56 & 0 & 0,00 & 0 & 0,00 \\
$700 \mathrm{~kg}$ & 5 & 13,89 & 7 & 28,00 & 3 & 17,65 \\
$600 \mathrm{~kg}$ & 2 & 13,89 & 1 & 4,00 & 1 & 5,88 \\
$500 \mathrm{~kg}$ & 3 & 5,56 & 1 & 4,00 & 2 & 35,76 \\
$400 \mathrm{~kg}$ & 0 & 8,33 & 2 & 8,00 & 6 & 17,65 \\
$350 \mathrm{~kg}$ & 0 & 0,00 & 0 & 0,00 & 3 & 0,00 \\
$200 \mathrm{~kg}$ & 1 & 0,00 & 0 & 0,00 & 0 & 0,00 \\
$100 \mathrm{~kg}$ & 0 & 2,78 & 0 & 0,00 & 0 & 0,00 \\
\hline Toplam & 36 & 0,00 & 0 & 0,00 & 0 & 100,00 \\
\hline
\end{tabular}

Ülkemizde üretilen üzümün yarıdan fazlası sofralık olarak değerlendirilmektedir (Sivritepe ve Parlak, 2015). Araştırmamızda da bu görülmektedir. Yeniköy üreticilerinin yetiştirdikleri üzümün $\% 40$ 'ını sofralık+şaraplık olarak; \%21'lik kısmını ise sofralık+şaraplık+diğer şekillerde değerlendirdikleri belirlenmiştir. Diğer kategorisinde pekmez, hardaliye ve üzüm şırası yer almıştır. Kırcasalih'te de benzer şekilde $\% 37$ oranında sofralık+ şaraplık + diğer şeklinde; \%31'inin ise şaraplık + diğer kategorisinde değerlendirdikleri saptanmıştır. Aslıhan üreticilerinin de \%50 oranında şaraplık+diğer; \%32,35'ini de sofralık+şaraplık+diğer olarak değerlendirdiği ortaya konmuştur.

\section{Sonuç ve Öneriler}

Bu çalışma sonucunda; Edirne ili Uzunköprü ilçesi Yeniköy mahallesinin bağcılık konusunda daha bilinçli ve modern çalışmalarla üretimi sürdürdüğü, bunu Kırcasalih beldesininin izlediği görülmüş̧ür. Aslıhan Köyü’nde 2015 yılında yağan aşırı yağmurlardan dolayı taşkın meydana gelmiş olup çoğu arazi uzun süre sular altında kalmıştır. Yaşanan bu sel felaketinden sonra bağlarda çok fazla kayıp meydana gelmiş, kurtarılmaya çalışılmışsa da birçok bağcı bağını sökme durumuna gelmiştir. Yapılan kapsamlı anket sonucunda; yöre bağlarının 10da'dan küçük olduğu ve Yeniköy mahallesinde Hamburg Misketi ve Alphonse Lavalleé çeşitlerinin, Kırcasalih beldesinde Papazkarası ve Merlot, Aslıhan köyünde ise Papazkarası ve Hamburg Misketi çeşitlerinin yetiştirildiği belirlenmiştir. Yeniköy'de ankete katılan bağcıların \%30,56's1 1000kg/da; Kırcasalih'te \%44'ü 1000kg/da ve Aslıhan'da \%35,29'unun 500kg/da sofralık üzüm verimi aldığ1 belirlenmiştir. Bu verim düşüktür, artırılmalıdır. Bu amaç doğrultusunda bağ kurmadan önce ve bağın verim aşamasında her yıl toprak analizi yaptırmak ve buna göre gübreleme uygulamak gereklidir. Ankete katılan bağcıların Yeniköy \%27,91; Kırcasalih \%31,58 ve Aslıhan \%5,88'i bağlarında sulama yapmaktadırlar. Bu oran çok düşük olduğundan yöredeki bağcıların verim ve kaliteyi artırmak için düzenli bir sulama yapmaları gerekmektedir. Üzümün pazarlanması aşamasında üreticilerin örgütlü olmamaları yöre bağcılığının sorunları arasındadır. Bu sorun için, üreticilerin bir örgüt çatısı altında birleşmeleri gerekmektedir. Ayrıca, düşük faizli krediler ve hibeler verilerek üreticilerin yeni bağ kurmaları teşvik edilebilir. Devamında kültürel işlemlerin eksiksiz ve zamanında yapılması da önemlidir, bunun için bağcıların programlı olarak eğitimi şarttır. Yörede hakim terbiye sisteminin Kordon Royat olduğu ortaya konmuştur. Yeniköy bağlarının \%81,40'1, Kırcasalih bağlarının \%71,05'i ve Aslıhan bağlarının $\% 47,06$ 's1 Kordon Royat şeklinde terbiye edilmiştir. Bu oran sadece Aslıhan köyünde \%50'nin altında kalmıştır. Bunun da sel felaketinin olumsuz etkisinden kaynaklandığı düşünülmektedir. Üreticilerin 
çoğunluğu bağlarını kimyasal gübreler kullanarak gübrelemektedirler. Yeniköy bağlarının \%72,09’u, Kırcasalih bağlarının \%71,05'i ve Aslıhan bağlarının \%61,76'sı kimyasal gübre kullanmaktadır. Üreticilerin kimyasal gübre ve pestisit kullanımı konusunda da bilgilendirilmesi ve bu şekilde çevre dostu yetiştiricilik tekniklerinin özendirilmesi yerinde olacaktır. Yöreye özgü Papazkarası çeşidinin yetiştiriciliğinin devam etmesi ve geliştirilmesi için gereken düzenlemelerin en kısa sürede yapılması da yerinde olacaktır.

\section{Kaynaklar}

Anonim, 2018a. www.tuik.gov.tr/PreTablo.do?alt_id=1001 (Erişim tarihi: 24.04.2018).

Anonim, 2018b. 2015 GTHB Brifing Raporu, Edirne. https://edirne.tarim.gov.tr/Belgeler/ 2015\%20Edirne\%20GTHB\%20Brifing\%20-\%20Kopya\%20(1).doc (Erişim tarihi: 24.04.2018).

Anonim, 2018c. Uzunköprü Gıda, Tarım ve Hayvancılık İlçe Müdürlüğü Kayıtları.

Anonim, 2018d. Uzunköprü Gıda, Tarım ve Hayvancılık İlçe Müdürlüğü Kayıtları.

Anonim, 2019. M. Meclisi Tutanakları. B:38, 09.02.1968, O:1. Ankara.

Bahar, E., Korkutal, İ., Kök, D., 2006. Türkiye bağcllığının son yıllardaki gelişiminde görülen başlıca sorunları ve çözüm önerileri. Trakya University Journal of Science. 7(1):65-69.

Baykul, A., Abacı, S.H., Abacı, N.İ, Söylemezoğlu, G., 2018. Bazı Anadolu illerinin bağcıllk açısından değerlendirilmesi. Bahçe 47 (Özel Sayı 1: Türkiye 9. Bağcıllk ve Teknolojileri Sempozyumu): 63-69.

Baykul, A., Söylemezoğlu, G., 2018. Eskişehir ili bağcılığına genel bir bakış. Bahçe 47 (Özel Sayı 1: Türkiye 9. Bağcılık ve Teknolojileri Sempozyumu): 71-75.

Çelik, H., Çelik, S., Kunter, B. M., Söylemezoğlu, G., Boz, Y., Özer, C., Atak, A., 2005. Bağcllıkta gelişme ve üretim hedefleri. VI. Türkiye Ziraat Mühendisliği Teknik Kongresi, 3-7 Ocak 2005, Ankara.

Çelik, H., 2019. Türkiye bağcılığı ve asma fidanı üretimi-dış ticareti ile ilgili stratejik bir değerlendirme. http://www.hasancelik.web.tr/Yayinlar/124.pdf, Erişim tarihi: 11.01.2019.

Çetin, E.S., Daler, S., 2018. Yozgat ili bağcılığının değerlendirilmesi. Bahçe 47 (Özel Sayı 1: Türkiye 9. Bağcllık ve Teknolojileri Sempozyumu): 209-218.

Dardeniz, A., Kaynaş, K., Ateş, F., 2001. Çanakkale ili bağcılığının mevcut durumu, sorunları ve çözüm önerileri. Bahçe. 30(1-2):25-35.

Dardeniz, A., 2013. Çanakkale Tarımı. Çanakkale ili bağcıllğı ve son gelişmeler. ÇOMÜ Ziraat Fakültesi Dergisi. 1(1):107-110.

Google Earth, 2019. Haritalar ve uydu görüntüleri. https://www.google.com.tr/maps/search/ (Erişim tarihi: 11.01.2019).

Göksu, A., Fuller, W.J., Altındişli, A., Boyacı, M., Abak, K., 2015. KKTC Bağcılığı: mevcut durumu sorunları ve çözüm önerileri. Selçuk Tarım ve Gıda Bilimleri Dergisi-A. 27 (Türkiye 8. Bağcılık ve Teknolojileri Sempozyumu Özel Sayıs1): 660-669.

Güler, D., 2014. Örnek Hacim Hesaplama. https://duranguler.com/ornek-hacmi-hesaplama/_Erişim tarihi: 21.03.2018).

Karataş, H., Karataş, D.D., Aslan, A., 2018. Siirt ili bağcllık potansiyeli. Bahçe 47 (Özel Sayı 1: Türkiye 9. Bağcllık ve Teknolojileri Sempozyumu): 311-314.

Kiracı, M.A., Şenol, M.A., Kıran, T., 2015. Türkiye bağ alanı ve üzüm üretiminin gelişimi ve yapısal analizi. Selçuk Tarım ve Gıda Bilimleri Dergisi-A. 27 (Türkiye 8. Bağcılık ve Teknolojileri Sempozyumu Özel Sayıs1): 739-755.

Kiraz, M.E., Kamiloğlu, Ö., Kavak, O., Subaşı, O.S., Uysal, O., 2016. Mersin ili bağcılığının teknik yapısı. Bahçe Özel Sayı: VII. Bahçe Bitkileri Kongresi Bildirileri, Cilt: II, Sebzecilik, Bağcılık ve Süs Bitkileri. 45: 748-753.

Korkutal, İ., Bahar, E., Erkan H.A., 2009. Edirne ili uzunköprü ilçesi yeniköy beldesi bağcllık yapısının incelenmesi. Trakya University Journal of Science. 10(2):179-187.

Miran, B., 2002. Temel İstatistik. Ege Üniversitesi Basımevi. ISBN:975-93088-0-0. İzmir. 288s.

Özatak, Ö.F., Doğan, A., Kazankaya, A., Uyak, C., 2018. Hakkari ili bağ yetiştiriciliğginin analizi. Bahçe 47 (Özel Sayı 1: Türkiye 9. Bağcılık ve Teknolojileri Sempozyumu): 443-450.

Polat, A., Gürsöz, S., Rastgeldi, İ., 2018. Şanlıurfa ilinde bağccllğın mevcut durumu. Bahçe 47 (Özel Sayı 1: Türkiye 9. Bağcllık ve Teknolojileri Sempozyumu): 87-90.

Savaş, Y., Çobanoğlu, F., Karabat, S., 2015. Asma fidanı üretiminin teknik ve ekonomik yönden mevcut durumu. Selçuk Tarım ve Gıda Bilimleri Dergisi-A. 27 (Türkiye 8. Bağcılık ve Teknolojileri Sempozyumu Özel Sayıs1): 426-435.

Semerci, A., Kızıltuğ, T., Çelik, A.D., Kiracı, M.A. Türkiye bağcllı̆̆ının genel durumu. Mustafa Kemal Üniversitesi Ziraat Fakültesi Dergisi. 20(2): 42-51. 
ÇOMÜ Zir. Fak. Derg. (COMU J. Agric. Fac.)

2019: 7 (1): 127-136

ISSN: $2147-8384$ / e-ISSN: 2564-6826

doi:10.33202/comuagri.457451

Sivritepe, N., Parlak, T.M., 2015. Türkiye ve dünyada sofralık üzüm üretimi, tüketimi ve ihracat profilinde meydana gelen değişimler. Selçuk Tarım ve Gıda Bilimleri Dergisi-A. 27 (Türkiye 8. Bağcılık ve Teknolojileri Sempozyumu Özel Sayısı): 56-68.

Utku, M., 2015. Şarap üretim işletmelerinde maliyet sistemi ve bir uygulama. Pamukkale Üniversitesi Sosyal Bilimler Enstitüsü Doktora Tezi. İşletme Anabilim Dalı Genel İşletme Programı. Denizli. 237s. 